\title{
Zeitschrift für Soziologie
}

\section{Inhalt / Contents}

\section{Soziologische Theorie / Social Theory}

314-329 Are Joiners Trusters?

Katrin Botzen

A Panel Analysis of Participation and Generalized Trust

Schulen Vereine das Vertrauen? Eine Panelanalyse über Partizipation und generalisiertes Vertrauen

\section{Wissenschaftssoziologie / Sociology of Science}

330-347 Digitale Inklusion: Zur sozialen Öffnung des Wissenschaftssystems

Digital Inclusion: The Social Implications of Open Science

Sascha Dickel \&

Martina Franzen

\section{Religions- und Migrationssoziologie / Sociology of Religion and Migration}

348-365 Die Entstehung interethnischer Kontakte von Neuzuwanderern aus Polen und der Türkei in Deutschland - eine Frage der Religion? The Acquisition of Interethnic Ties among Recent Immigrants from Poland and Turkey in Germany - a Matter of Religion?

\section{Bildungsungleichheit / Educational Inequality}

366-382 Hochschulrankings als Kriterium für neue soziale Ungleichheit im tertiären Bildungssystem?

University Rankings as a New Criterion of Social Inequality in Higher Education?

Felix Weiss, Steffen Schindler \& Maria Gerth 